\title{
Ochrobactrum cytisi sp. nov., isolated from nodules of Cytisus scoparius in Spain
} Correspondence
Encarna Velázquez
evp@usal.es

\author{
José Luis Zurdo-Piñeiro, ${ }^{1}$ Raúl Rivas, ${ }^{1} \dagger$ Martha E. Trujillo, ${ }^{1}$ \\ Nieves Vizcaíno, ${ }^{1}$ José Antonio Carrasco, ${ }^{2}$ Manuel Chamber, ${ }^{2}$ \\ Antonio Palomares, ${ }^{3}$ Pedro F. Mateos, ${ }^{1}$ Eustoquio Martínez-Molina ${ }^{1}$ \\ and Encarna Velázquez ${ }^{1}$
${ }^{1}$ Departamento de Microbiología y Genética, Universidad de Salamanca, Salamanca, Spain
${ }^{2}$ CIFA Las Torres, Alcalá del Río, Sevilla, Spain
${ }^{3}$ Departamento de Microbiología y Parasitología, Facultad de Farmacia, Universidad de Sevilla, Sevilla, Spain

\begin{abstract}
Two strains named ESC $1^{\top}$ and ESC5 were isolated from nodules of Cytisus scoparius growing in a Spanish soil. Phylogenetic analysis of the 16S rRNA gene showed that these strains belong to the genus Ochrobactrum, their closest relatives being Ochrobactrum anthropi and Ochrobactrum lupini, with 100 and $99.9 \%$ similarity to the respective type strains. Despite this high similarity, the results of DNA-DNA hybridization, phenotypic tests and fatty acid analyses showed that these strains represent a novel species of genus Ochrobactrum. The DNA-DNA hybridization values were respectively 70,66 and $55 \%$ with respect to O. Iupini LUP $21^{\top}$, O. anthropi DSM $6882^{\top}$ and Ochrobactrum tritici DSM $13340^{\top}$. The predominant fatty acids were $\mathrm{C}_{18: 1} \omega 7 \mathrm{c}$ and $\mathrm{C}_{18: 1} 2-\mathrm{OH}$. Strains $E S C 1^{\top}$ and ESC5 were strictly aerobic and were able to reduce nitrate and to hydrolyse aesculin. They produced $\beta$-galactosidase and $\beta$-glucosidase and did not produce urease after $48 \mathrm{~h}$ incubation. The $\mathrm{G}+\mathrm{C}$ content of strain $\mathrm{ESC}_{1}{ }^{\top}$ was $56.4 \mathrm{~mol} \%$. Both strains $\mathrm{ESC} 1^{\top}$ and ESC5 contained nodD and nifH genes on megaplasmids that were related phylogenetically to those of rhizobial strains nodulating Phaseolus, Leucaena, Trifolium and Lupinus. From the results of this work, we propose that the strains isolated in this study be included in a novel species

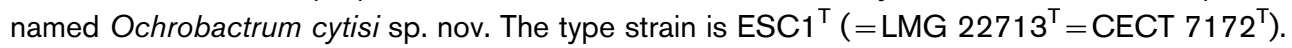

The genus Ochrobactrum currently contains six species, including human pathogens such as Ochrobactrum anthropi (Holmes et al., 1988), rhizospheric bacteria such as Ochrobactrum tritici (Lebuhn et al., 2000) and legume endosymbionts such as Ochrobactrum lupini (Trujillo et al., 2006). The strains of the latter species carry symbiotic genes nodD and nifH phylogenetically related to those of different rhizobial strains nodulating Phaseolus and Cicer,

tPresent address: Laboratorium voor Microbiologie, Vakgroep Biochemie, Fysiologie en Microbiologie, Universiteit Gent, K. L. Ledeganckstraat 35, B-9000 Gent, Belgium.

Abbreviations: ITS, intergenic spacer; TP-RAPD, two-primers randomly amplified polymorphic DNA.

The GenBank/EMBL/DDBJ accession numbers for the 16S rRNA, nifH and nodD gene sequences of strain $\mathrm{ESCl}^{\top}$ are AY776289AY776291, respectively.

TP-RAPD profiles, nifH- and nodD-based neighbour-joining trees, photos of nodules induced by strain $\mathrm{ESC} 1^{\top}$ and $R$. etli $\mathrm{CFN} 42^{\top}$, fatty acid profiles and differentiating characters for all species of Ochrobactrum are available as supplementary material in IJSEM Online. respectively (Trujillo et al., 2005). In this work, we isolated two strains named $\mathrm{ESCl}^{\mathrm{T}}$ and ESC5 from Cytisus scoparius nodules in a contaminated soil from southern Spain (Sevilla) near to the Guadiamar river, which has received spills from the Aznalcollar mines containing several heavy metals. The data obtained in this study show that these strains belong to a novel species of Ochrobactrum.

Strains $\mathrm{ESC}^{\mathrm{T}}$ and ESC5 were isolated from root nodules of Cytisus scoparius according to Vincent (1970) using yeast mannitol agar (YMA; Bergersen, 1961). The cultures used in further phenotypic and molecular studies were purified from a single colony after 2 days incubation at $28{ }^{\circ} \mathrm{C}$ on YMA. The colonies were white, mucoid, translucent and convex on this medium.

Sequencing of the nearly complete $16 \mathrm{~S}$ rRNA gene was performed as described previously (Rivas et al., 2002b). The 16S-23S rRNA intergenic spacer (ITS) region was amplified and sequenced as described by Lebuhn et al. (2006). Sequence comparison and alignment were performed by using the BLASTN program (Altschul et al., 1990) and 


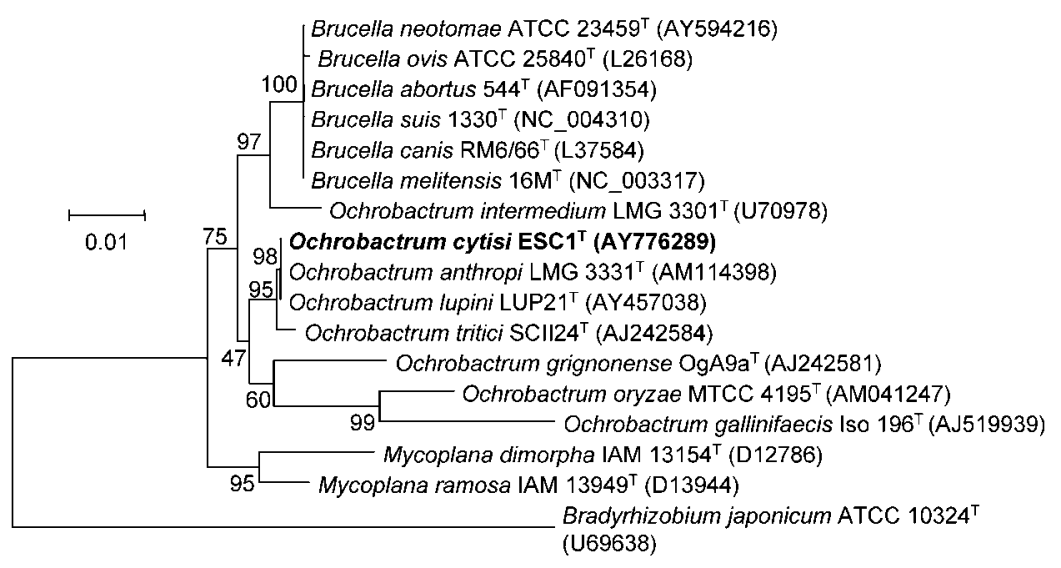

Fig. 1. Comparative sequence analysis of $16 \mathrm{~S}$ rRNA genes of strain $\mathrm{ESC}^{\top}{ }^{\top}$ and representative related species. The tree was constructed by the neighbour-joining method. The significance of each branch is indicated by a bootstrap percentage calculated for 1000 subsets. Bar, 1 substitution per 100 nucleotide positions.
CLUSTAL W software (Thompson et al., 1997), respectively. Distances were calculated according to Kimura's twoparameter model (Kimura, 1980). Phylogenetic trees were inferred using the neighbour-joining method (Saitou \& Nei, 1987). Bootstrap analysis was based on 1000 resamplings. The MEGA2 package (Kumar et al., 2001) was used for all analyses.

The 16S rRNA gene ( $\mathrm{rrn}$ ) sequences obtained (1476 nucleotides) were identical in strains ESC1 ${ }^{\mathrm{T}}$ and ESC5 and showed 100, 99.9 and $99.7 \%$ similarity, respectively, to sequences from $O$. anthropi LMG $3331^{\mathrm{T}}$, O. lupini LUP $21^{\mathrm{T}}$ and $O$. tritici LMG $18957^{\mathrm{T}}$. Phylogenetic analysis of $16 \mathrm{~S}$ rRNA gene sequences of the strains from this study showed clearly that they form a separate group within the genus Ochrobactrum together with O. anthropi, O. lupini and O. tritici, being most closely related to the first two of these species (Fig. 1).

Sequence comparison of 16S-23S rRNA ITS regions provides a fast way of assessing relatedness between species of the genus Ochrobactrum because good correlations have been found among ITS1 and rrn sequences and DNA-DNA hybridization values (Lebuhn et al., 2006). Therefore this region was sequenced in strains $\mathrm{ESC}^{\mathrm{T}}$ and ESC5 and in $O$. lupini LUP21 $1^{\mathrm{T}}$. In agreement with phylogenetic analyses based on the rrn sequences, phylogenetic analysis of the ITS sequences showed that the strains from this study are closely related to O. anthropi, O. lupini and O. tritici (Fig. 2). A pairwise analysis of the ITS sequences showed 91.8, 92.7 and 86.2\% identity between strain ESC $1^{\mathrm{T}}$ and $O$. lupini LUP $21^{\mathrm{T}}$, O. anthropi LMG $3331^{\mathrm{T}}$ and O. tritici LMG $18957^{\mathrm{T}}$, respectively. These values were lower than that found between $O$. anthropi LMG $3331^{\mathrm{T}}$ and O. tritici LMG $18957^{\mathrm{T}}(94.0 \%)$ and suggested that the strains isolated in this work belong to a separate species within the genus Ochrobactrum.

Two-primers randomly amplified polymorphic DNA (TPRAPD) patterns were analysed according to the method described by Rivas et al. (2002a) using the primer pair $8 \mathrm{~F}$ (5'-AGAGTTTGATCCTGGCTCAG-3') and 1522R (5'-AAGGAGGTGATCCANCCRCA-3') and also the primer pair 879F $\left(5^{\prime}\right.$-GCCTGGGGAGTACGGCCGCA-3') and 1522R (5' AAGGAGGTGATCCANCCRCA-3'), which correspond to Escherichia coli positions 8-27, 879-898 and 1509-1522, respectively. TP-RAPD patterns of strains from the same species are identical (Rivas et al., 2001, 2004) and allowed differentiation among $O$. anthropi, O. lupini and O. tritici (Trujillo et al., 2005). Therefore, we analysed the TP-RAPD patterns of strains $\mathrm{ESCl}^{\mathrm{T}}$ and ESC5 in comparison with those of the type strains from these three species (Supplementary Fig. S1). Strains ESC1 ${ }^{\mathrm{T}}$ and ESC5 showed identical TP-RAPD patterns (Supplementary Fig. S1, lanes 1 and 2 and lanes 6 and 7), suggesting that they belong to the same species. The TP-RAPD patterns obtained with the two

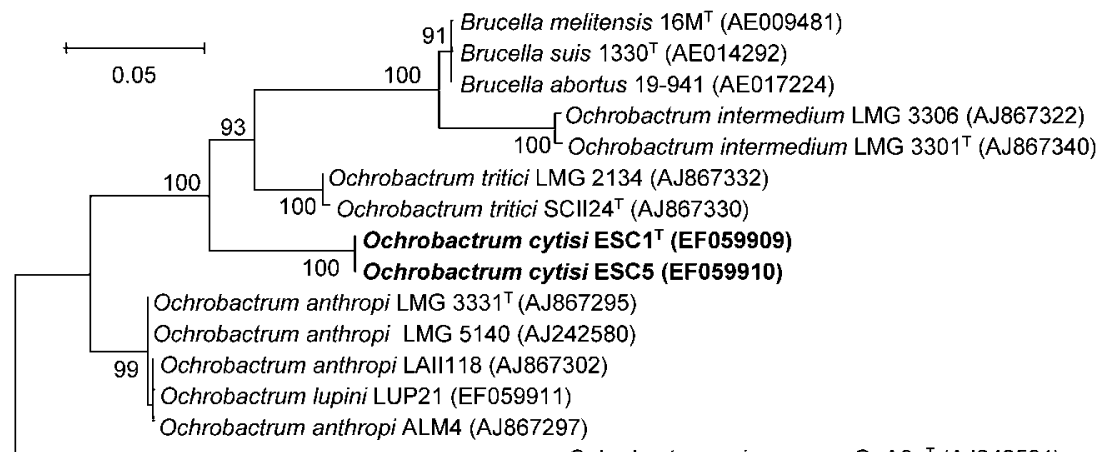

Ochrobactrum grignonense OgA9a ${ }^{\top}$ (AJ242581)

100 Ochrobactrum grignonense OgA9c (AJ867326)
Fig. 2. Comparative sequence analysis of the 16S-23S rRNA ITS regions of strain $E S C 1^{\top}$ and representative related species. The tree was constructed by the neighbourjoining method. The significance of each branch is indicated by a bootstrap percentage calculated for 1000 subsets. Bar, 5 substitutions per 100 nucleotide positions. 
primer pairs used in this study differ from those of $O$. tritici (lanes 3 and 8), O. anthropi (lanes 4 and 9) and O. lupini (lanes 5 and 10). These results are congruent with the ITS sequence data and suggest that the strains from this study belong to a different species.

The $\mathrm{G}+\mathrm{C}$ content of strain $\mathrm{ESCl}^{\mathrm{T}}$ was $56.4 \mathrm{~mol} \%$, as determined by HPLC (Rivas et al., 2003). DNA-DNA hybridization analyses were performed at the DSMZ. DNA was isolated by chromatography on hydroxyapatite by the procedure of Cashion et al. (1977), which was carried out as described by De Ley et al. (1970) with the modifications described by Huß et al. (1983) and Escara \& Hutton (1980). Renaturation rates were computed with the TRANSFER.BAS program (Jahnke, 1992) and DNA-DNA relatedness was tested at $68{ }^{\circ} \mathrm{C}$ in $2 \times$ SSC plus $10 \%(\mathrm{v} / \mathrm{v})$ DMSO. The resulting values between strain $\mathrm{ESCl}^{\mathrm{T}}$ and strains $O$. lupini LUP2 $1^{\mathrm{T}}$, O. anthropi DSM $6882^{\mathrm{T}}$ and O. tritici DSM $13340^{\mathrm{T}}$ were $70.4 \%$ (individual values 69.8 and $71.0 \%$ ), $65.8 \%$ (68.9 and $62.6 \%$ ) and $54.5 \%$ (55.3 and $53.7 \%$ ), respectively (means of duplicates). The values obtained between $O$. lupini LUP2 $1^{\mathrm{T}}$ and O. anthropi DSM $6882^{\mathrm{T}}$ and O. tritici DSM $13340^{\mathrm{T}}$ were 69 and $63 \%$, respectively (means of duplicates). These values were nearly identical to those obtained in a previous work for $O$. lupini $\operatorname{LUP} 21^{\mathrm{T}}$ and $O$. anthropi LMG $3331^{\mathrm{T}}$ using a different method for DNADNA hybridization (Trujillo et al., 2005).

Fatty acids were extracted and analysed at the LMG as described previously (Trujillo et al., 2005). The fatty acid pattern of strain $\mathrm{ESCl}^{\mathrm{T}}$ (Supplementary Table S1) confirmed that it is a member of the genus Ochrobactrum, because it contains a major amount of $\mathrm{C}_{18: 1} \omega 7 c$ and moderate amounts (1-10\%) of $\mathrm{C}_{16: 0}, \mathrm{C}_{17: 0}, \mathrm{C}_{18: 0}, \mathrm{C}_{19: 0}$ cyclo $\omega 8 c$ and summed feature $3\left(\mathrm{C}_{16: 1} \omega 7 c\right.$ and/or $\mathrm{C}_{15: 0}$ iso 2-OH). Like other Ochrobactrum species, strain ESC1 ${ }^{\mathrm{T}}$ contains $\mathrm{C}_{18: 1} 2-\mathrm{OH}$, but the amounts detected in strains $\operatorname{ESC1}^{\mathrm{T}}(20.4 \%)$ and ESC5 (14.2\%) were higher than in their closest relatives $O$. anthropi and O. lupini. The novel strains also differ from $O$. anthropi in the amount of $\mathrm{C}_{19: 0}$ cyclo $\omega 8 c$. Several fatty acids present in small amounts in some closely related species were not detected in the strains from this study (see Supplementary Table S1).

Cells were stained according to the classical Gram procedure as described by Doetsch (1981) and motility was checked by phase-contrast microscopy. Catalase and oxidase activities were tested as described previously (Rivas et al., 2003). Physiological studies were done using API 20NE and API $20 \mathrm{E}$ systems following the manufacturer's instructions (bioMérieux). API $50 \mathrm{CH}$ strips were inoculated with suspensions of the strains in a basal medium containing YNB (yeast nitrogen base; Difco) adjusted to $\mathrm{pH}$ 7. For API ZYM strips, suspensions of cells growing for $24 \mathrm{~h}$ on TSA plates were used for inoculation as recommended by the manufacturer. Susceptibility to various antibiotics was examined as described previously (Valverde et al., 2005) using discs (Becton Dickinson) containing (per disc) penicillin $(10 \mathrm{U})$, ampicillin $(2 \mu \mathrm{g})$, oxytetracycline $(30 \mu \mathrm{g})$, neomycin $(5 \mu \mathrm{g})$, cloxacillin $(1 \mu \mathrm{g})$, erythromycin $(2 \mu \mathrm{g})$, cefuroxime $(30 \mu \mathrm{g})$, ciprofloxacin $(5 \mu \mathrm{g})$, polymyxin $\mathrm{B}$ $(300 \mathrm{IU})$ and gentamicin $(10 \mu \mathrm{g})$ and antibiotic agar 11 (Oxoid) as the basal medium. O. lupini strains LUP2 $1^{\mathrm{T}}$ and LUP23, O. tritici LMG $18957^{\mathrm{T}}$ and O. anthropi LMG $3331^{\mathrm{T}}$ were used as references in phenotypic characterization studies.

Cells of strains ESC1 ${ }^{\mathrm{T}}$ and ESC5 were Gram-negative, rodshaped, non-sporulating, motile by means of a polar flagellum and commonly observed as single cells. Strains $\mathrm{ESCl}^{\mathrm{T}}$ and ESC5 differ in the production of $\beta$-galactosidase in API ZYM (Table 1 and Supplementary Table S2). They differ from $O$. lupini in nitrate reduction, urease production after $48 \mathrm{~h}$ incubation and gluconate, D-arabinose, D-turanose and L-lyxose assimilation and from O. anthropi in aesculin hydrolysis, urease production after $48 \mathrm{~h}$ incubation, production of $\beta$-galactosidase in API ZYM, citrate $(24 \mathrm{~h})$ and gluconate assimilation and resistance to polymyxin $\mathrm{B}$. The two strains differ from $O$. tritici in aesculin hydrolysis, urease production after $24 \mathrm{~h}$ incubation, production of $\beta$-galactosidase, $\alpha$-glucosidase and lipase

Table 1. Differentiating physiological characters between the novel strains and the closest phylogenetically related species of genus Ochrobactrum

Taxa: 1, strain $\mathrm{ESCl}^{\mathrm{T}}$; 2, strain ESC5; 3, O. lupini (unless indicated, data from Trujillo et al., 2005); 4, O. anthropi (unless indicated, data from Holmes et al., 1988); 5, O. tritici (unless indicated, data from Lebuhn et al., 2000). +, Positive; -, negative; V, variable; W, weak; ND, no data; S, sensitive; R, resistant; I, intermediate.

\begin{tabular}{|lccccc|}
\hline Character & $\mathbf{1}$ & $\mathbf{2}$ & $\mathbf{3}$ & $\mathbf{4}$ & $\mathbf{5}$ \\
\hline Nitrate reduction & + & + & - & + & + \\
Aesculin hydrolysis & + & + & + & - & - \\
Urease (48 h) & - & - & + & + & + \\
API ZYM tests & & & & & \\
$\quad \beta$-Galactosidase & + & - & $\mathrm{V}^{*}$ & - & $-\dagger$ \\
$\quad \alpha$-Glucosidase & + & + & $\mathrm{W}^{*}$ & $+\ddagger$ & $-\dagger$ \\
Lipase C14 & + & + & $\mathrm{W}^{*}$ & $+\ddagger$ & $-\dagger$ \\
Assimilation of: & & & & & \\
Gluconate & - & - & + & + & + \\
Citrate (24 h) & $\mathrm{W}$ & + & + & - & - \\
D-Mannose & + & + & + & + & - \\
L-Arabinose & + & + & + & + & - \\
D-Arabinose & + & + & - & + & $\mathrm{ND}$ \\
D-Turanose & + & + & - & + & + \\
L-Lyxose & + & + & - & + & $\mathrm{ND}$ \\
Antibiotic resistance & & & & & \\
Chloramphenicol & $\mathrm{R}$ & $\mathrm{R}$ & $\mathrm{S}-\mathrm{I}$ & $\mathrm{R}$ & $\mathrm{I}$ \\
Polymyxin B (300 IU) & $\mathrm{R}$ & $\mathrm{R}$ & $\mathrm{R}$ & $\mathrm{S}$ & $\mathrm{S}$ \\
\hline
\end{tabular}

${ }^{\star}$ Data from this study for O. Iupini LUP $21^{\mathrm{T}}$ and LUP23.

$\dagger$ Data from this study for O. tritici LMG $18957^{\mathrm{T}}$.

$\$$ Data from this study for O. anthropi LMG $3331^{\mathrm{T}}$; reported as negative by Holmes et al. (1988). 
C14 in API ZYM and citrate, D-mannose and L-arabinose assimilation and in resistance to polymyxin B.

Partial sequences of nodD (296 nt) and nifH (320 nt) genes were amplified by PCR and sequenced as described previously (Rivas et al., 2002b). The nodD and nifH sequences of strains $\mathrm{ESCl}^{\mathrm{T}}$ and ESC5 were identical (data not shown). A comparison of the nifH gene sequence of the strains from this study against those held in databases showed that it is closely related ( $98.7 \%$ similarity) to the nifH gene of Ensifer sp. GR-06 and GR-X8, two strains isolated from Phaseolus vulgaris in Spain near to Sevilla (Herrera-Cervera et al., 1999) (Supplementary Fig. S2). The nodD gene sequence is closely related ( $97.2 \%$ similarity) to the nodD genes of strains of Rhizobium rhizogenes (Supplementary Fig. S3), a species recently found to be able to nodulate Phaseolus (Velázquez et al., 2005), and Ensifer sp. Br816, a strain with a broad host range able to nodulate Phaseolus vulgaris, Leucaena and Trifolium (van Rhijn et al., 1996). These results are in agreement with those obtained in previous studies showing the lateral transfer of symbiotic genes from rhizobia to several non-rhizobia from the Alphaproteobacteria in the rhizosphere (Rivas et al., 2002b; Sy et al., 2001; Trujillo et al., 2005; van Berkum \& Eardly, 2002). Concretely, the results of nodD and nifH gene sequencing suggest that the strains from this study have acquired these genes from rhizobia nodulating hosts from the cross-inoculation group of Phaseolus. Therefore, Phaseolus vulgaris was used to confirm nodulation by strains $\mathrm{ESCl}^{\mathrm{T}}$ and ESC5 as described previously (Velázquez et al., 2005). Rhizobium etli CFN $42^{\mathrm{T}}$ was used as a positive control. As a negative control, $P$. vulgaris plants were watered with nitrogen-free Rigaud and Puppo solution. Both strains generated nodules on P. vulgaris after 6 weeks inoculation. They formed white nodules (Supplementary Fig. S4a) with a morphology similar to that of nodules induced by $R$. etli CFN42 ${ }^{\mathrm{T}}$ (Supplementary Fig. S4b), although they were white and smaller in size than those elicited by $R$. etli. Plants inoculated with these strains developed a significantly smaller number of nodules than those inoculated with $R$. etli CFN42 ${ }^{\mathrm{T}}$ (data not shown).

In summary, on the basis of $16 \mathrm{~S}$ rRNA gene and 16S-23S rRNA ITS sequences, strains ESC1 ${ }^{\mathrm{T}}$ and ESC 5 belong to the genus Ochrobactrum, being closely related to O. anthropi, $O$. lupini and O. tritici. Nevertheless, DNA-DNA hybridization values and chemotaxonomic and phenotypic data indicate that they represent a taxon that merits species status within the genus Ochrobactrum, for which the name Ochrobactrum cytisi sp. nov. is proposed.

\section{Description of Ochrobactrum cytisi sp. nov.}

Ochrobactrum cytisi (cy.ti'si. N.L. masc. n. Cytisus botanical genus name of the legume Cytisus scoparius; N.L. gen. n. cytisi of Cytisus, referring to the isolation source of the first strains, nodules of C. scoparius).

Cells are motile, non-spore-forming, Gram-negative rods. Good growth occurs on YMA and nutrient agar at $25-30{ }^{\circ} \mathrm{C}$.
Colonies on these media are white to beige, mucoid with entire edges and $2-3 \mathrm{~mm}$ in diameter within $24 \mathrm{~h}$. Oxidaseand catalase-positive. The fatty acid profile is composed mainly of $\mathrm{C}_{18: 1} \omega 7 c, \mathrm{C}_{18: 1} 2-\mathrm{OH}, \mathrm{C}_{19: 0}$ cyclo $\omega 8 c$ and $\mathrm{C}_{16: 0}$. The following fatty acids are detected in small amounts: summed features 2 and 3, $\mathrm{C}_{18: 0}, \mathrm{C}_{17: 0}, \mathrm{C}_{18: 0} 2-\mathrm{OH}$ and an unknown fatty acid at ECL 11.799. The following tests were done by using API 20E and API 20NE systems. Nitrate is reduced to nitrite. Voges-Proskauer reaction, indole production and aesculin hydrolysis are positive. Production of $\beta$-galactosidase is variable. Production of urease (after $48 \mathrm{~h}$ incubation), arginine dihydrolase, lysine decarboxylase, ornithine decarboxylase and gelatinase is negative. Carbon sources utilized include D-glucose, L-arabinose, D-mannose, mannitol, $\mathrm{N}$-acetylglucosamine, maltose, citrate, erythritol, D-arabinose, ribose, adonitol, dulcitol, L-rhamnose, arbutin, maltose, sucrose, turanose, L-lyxose, tagatose, D-fucose, L-fucose, arabitol, 2-ketogluconate and 5-ketogluconate. Assimilation of D-xylose, L-xylose, galactose, D-fructose, lactose, melibiose, cellobiose, trehalose, dulcitol, glycerol, inositol, methyl $\alpha$-D-glucoside and gluconate is weak. Caprate, adipate, methyl $\beta$-D-xyloside, L-sorbose, sorbitol, methyl $\alpha$-Dmannoside, amygdalin, salicin, inulin, melezitose, D-raffinose, starch, glycogen, xylitol, $\beta$-gentiobiose and L-arabitol are not assimilated. The following enzymes are detected by using API ZYM strips: alkaline and acid phosphatases, esterase C4, lipase C8, lipase C14, leucine aminopeptidase, valine aminopeptidase, cystine aminopeptidase, trypsin, chymotrypsin, phosphoamidase, $\beta$-galactosidase and $\alpha$-glucosidase. Production of $N$-acetyl- $\beta$-glucosaminidase, $\alpha$-galactosidase, $\beta$-glucuronidase, $\beta$-glucosidase, $\alpha$-mannosidase and $\alpha$-fucosidase is negative. Resistant to ampicillin, penicillin, cefuroxime, cloxacillin, oxytetracycline, polymyxin B, erythromycin, neomycin and chloramphenicol. Sensitive to ciprofloxacin and weakly sensitive to gentamicin. The $\mathrm{G}+\mathrm{C}$ content of the type strain is $56.4 \mathrm{~mol} \%$.

The type strain, $\mathrm{ESCl}^{\mathrm{T}}\left(=\mathrm{LMG} 22713^{\mathrm{T}}=\mathrm{CECT} 7172^{\mathrm{T}}\right)$, and strain ESC5 ( = LMG 23703) were isolated from nodules of Cytisus scoparius.

\section{Acknowledgements}

This work was supported by funds from the Junta de Castilla y León to E.M.-M., MCYT to E.V. and the Spanish Ministerio de Medio Ambiente to A. P. and M. C.

\section{References}

Altschul, S. F., Gish, W., Miller, W., Myers, E. W. \& Lipman, D. J. (1990). Basic local alignment search tool. J Mol Biol 215, 403-410.

Bergersen, F. J. (1961). The growth of Rhizobium in synthetic media. Aust J Biol 14, 349-360.

Cashion, P., Holder-Franklin, M. A., McCully, J. \& Franklin, M. (1977). A rapid method for the base ratio determination of bacterial DNA. Anal Biochem 81, 461-466.

De Ley, J., Cattoir, H. \& Reynaerts, A. (1970). The quantitative measurement of DNA hybridization from renaturation rates. Eur J Biochem 12, 133-142. 
Doetsch, R. N. (1981). Determinative methods of light microscopy. In Manual of Methods for General Bacteriology, pp. 21-33. Edited by P. Gerhardt, R. G. E. Murray, R. N. Costilow, E. W. Nester, W. A. Wood, N. R. Krieg \& G. H. Phillips. Washington, DC: American Society for Microbiology.

Escara, J. F. \& Hutton, J. R. (1980). Thermal stability and renaturation of DNA in dimethyl sulfoxide solutions: acceleration of the renaturation rate. Biopolymers 19, 1315-1327.

Herrera-Cervera, J. A., Caballero-Mellado, J., Laguerre, G., Tichy, H.-V., Requena, N., Amarger, N., Martínez-Romero, E., Olivares, J., \& Sanjuán, J. (1999). At least five rhizobial species nodulate Phaseolus vulgaris in a Spanish soil. FEMS Microbiol Ecol 30, 87-97.

Holmes, B., Popoff, M., Kiredjian, M. \& Kersters, K. (1988). Ochrobactrum anthropi gen. nov., sp. nov. from human clinic specimens and previously known as group Vd. Int J Syst Bacteriol 38, 406-416.

Huß, V. A. R., Festl, H. \& Schleifer, K. H. (1983). Studies on the spectrophotometric determination of DNA hybridization from renaturation rates. Syst Appl Microbiol 4, 184-192.

Jahnke, K. D. (1992). BASIC computer program for evaluation of spectroscopic DNA renaturation data from Gilford System 2600 spectrophotometer on a PC/XT/AT type personal computer. J Microbiol Methods 15, 61-73.

Kimura, M. (1980). A simple method for estimating evolutionary rates of base substitutions through comparative studies of nucleotide sequences. J Mol Evol 16, 111-120.

Kumar, S., Tamura, K., Jakobsen, I.-B. \& Nei, M. (2001). Molecular evolutionary genetics analysis software. Tempe, AZ: Arizona State University.

Lebuhn, M., Achouak, W., Schloter, M., Berge, O., Meier, H., Barakat, M., Hartmann, A. \& Heulin, T. (2000). Taxonomic characterization of Ochrobactrum sp. isolates from soil samples and wheat roots and description of Ochrobactrum tritici sp. nov. and Ochrobactrum grignonense sp. nov. Int J Syst Evol Microbiol 50, 2207-2223.

Lebuhn, M., Bathe, S., Achouak, W., Hartmann, A., Heulin, T. \& Schloter, M. (2006). Comparative sequence analysis of the internal transcribed spacer 1 of Ochrobactrum species. Syst Appl Microbiol 29, 265-275.

Rivas, R., Velázquez, E., Valverde, A., Mateos, P. F. \& MartínezMolina, E. (2001). A two primers random amplified polymorphic DNA procedure to obtain polymerase chain reaction fingerprints of bacterial species. Electrophoresis 22, 1086-1089.

Rivas, R., Velázquez, E., Palomo, J.-L., Mateos, P. F., GarciaBenavides, P. \& Martínez-Molina, E. (2002a). Rapid identification of Clavibacter michiganensis subspecies sepedonicus using two primers random amplified polymorphic DNA (TP-RAPD) fingerprints. Eur J Plant Pathol 108, 179-184.

Rivas, R., Velázquez, E., Willems, A., Vizcaíno, N., Subba-Rao, N. S., Mateos, P. F., Gillis, M., Dazzo, F. B. \& Martínez-Molina, E. (2002b). A new species of Devosia that forms a nitrogen-fixing root-nodule symbiosis with the aquatic legume Neptunia natans (L. f.) Druce. Appl Environ Microbiol 68, 5217-5222.

Rivas, R., Willems, A., Subba-Rao, N. S., Mateos, P. F., Dazzo, F. B., Martínez-Molina, E., Gillis, M. \& Velázquez, E. (2003). Description of Devosia neptuniae sp. nov. that nodulates and fixes nitrogen in symbiosis with Neptunia natans, an aquatic legume from India. Syst Appl Microbiol 26, 47-53.

Rivas, R., Abril, A., Trujillo, M. E. \& Velázquez, E. (2004). Sphingomonas phyllosphaerae sp. nov., from the phyllosphere of Acacia caven in Argentina. Int J Syst Evol Microbiol 54, 2147-2150.

Saitou, N. \& Nei, M. (1987). The neighbor-joining method: a new method for reconstructing phylogenetic trees. Mol Biol Evol 4, 406-425.

Sy, A., Giraud, E., Jourand, P., García, N., Willems, A., de Lajudie, A. P., Prin, Y., Neyra, M., Gillis, M. \& other authors (2001). Methylotrophic Methylobacterium bacteria nodulate and fix nitrogen in symbiosis with legumes. J Bacteriol 183, 214-220.

Thompson, J. D., Gibson, T. J., Plewniak, F., Jeanmougin, F. \& Higgins, D. G. (1997). The CLUSTAL_X windows interface: flexible strategies for multiple sequence alignment aided by quality analysis tools. Nucleic Acids Res 25, 4876-4882.

Trujillo, M. E., Willems, A., Abril, A., Planchuelo, A. M., Rivas, R., Ludeña, D., Mateos, P. F., Martínez-Molina, E. \& Velázquez, E. (2005). Nodulation of Lupinus by strains of the new species Ochrobactrum lupini sp. nov. Appl Environ Microbiol 71, 1318-1327.

Trujillo, M. E., Willems, A., Abril, A., Planchuelo, A. M., Rivas, R., Ludeña, D., Mateos, P. F., Martínez-Molina, E. \& Velázquez, E. (2006). Ochrobactrum lupini sp. nov. In List of New Names and New Combinations Previously Effectively, but not Validly, Published, List no. 110. Int J Syst Evol Microbiol 56, 1459-1460.

Valverde, A., Velázquez, E., Fernández-Santos, F., Vizcaino, N., Rivas, R., Mateos, P. F., Martinez-Molina, E., Igual, J. M. \& Willems, A. (2005). Phyllobacterium trifolii sp. nov., nodulating Trifolium and Lupinus in Spanish soils. Int J Syst Evol Microbiol 55, 1985-1989.

van Berkum, P. \& Eardly, B. (2002). The aquatic budding bacterium Blastobacter denitrificans is a nitrogen fixing symbiont of Aeschynomene indica. Appl Environ Microbiol 68, 1132-1136.

van Rhijn, P., Luyten, E., Vlassak, K. \& Vanderleyden, J. (1996). Isolation and characterization of a pSym locus of Rhizobium sp. BR816 that extends nodulation ability of narrow host range Phaseolus vulgaris symbionts to Leucaena leucocephala. Mol Plant Microbe Interact 9, 74-77.

Velázquez, E., Peix, A., Zurdo-Piñeiro, J. L., Palomo, J. L., Mateos, P. F., Rivas, R., Muñoz-Adelantado, E., Toro, N., García-Benavides, P. \& other authors (2005). The coexistence of symbiosis and pathogenicity-determining genes in Rhizobium rhizogenes strains enables them to induce nodules and tumours or hairy roots in plants. Mol Plant Microbe Interact 18, 1325-1332.

Vincent, J. M. (1970). The cultivation, isolation and maintenance of rhizobia. In A Manual for the Practical Study of the Root-Nodule Bacteria, pp. 1-13. Oxford: Blackwell Scientific. 